Mertens nevertheless provided a concise and accurate report on the progress of the Moscow plague. His account, now reproduced in a facsimile edition, illuminates clearly three important facets of the struggle against the plague: the devoted service of medical personnel faced with a terrifying crisis and working among a panic-stricken and frequently hostile populace, the utter helplessness of physicians armed with a medical knowledge little advanced since Galen's time, and the acrimonious disputes of doctors over the causes and treatment of the disease.

An introductory essay by John T. Alexander places the Moscow epidemic in historical context and contrasts the social and political repercussions of this outbreak with those of the London plague of 1665 . He also analyzes official British responses to the news of the 1770-71 plague in eastern Europe and tells how protective measures often had to be developed on the basis of alarmingly misleading and inaccurate information about the course of the epidemic. The edition would have been strengthened by some background on Mertens's disputes with other government medical counselors, issues that frequently turn up in the text and original notes but are nowhere fully explained. Presumably Alexander will elaborate on these interesting policy confrontations in his forthcoming monograph on the Moscow plague.

David L. Ransel

University of Illinois at Urbana-Champaign

\title{
DIE EUROPÄISCHE ALLIANZPOLITIK ALEXANDERS I. UND DER GRIECHISCHE UNABHÄNGIGKEITSKAMPF, 1820-1830. By Eberhard Schütz. Veröffentlichungen des Osteuropa-Instituts München, vol. 43. Wies- baden: Otto Harrassowitz in Kommission, 1975. viii, 153 pp. DM 28, paper.
}

This is a competent short study, based entirely upon printed materials, of the difficulties created for Alexander I by the outbreak of the Greek war of independence and of his unsuccessful efforts to resolve them. Dr. Schütz's central theme is not new. On the one hand the tsar wished to press home claims on Turkey with regard to the Danubian Principalities, the Caucasus, and the right of free passage for Russian merchantmen through the Straits. On the other he was deeply unwilling to do anything which seemed to aid the cause of revolt against the legitimate ruler or to encourage the forces of disorder which, he believed, threatened peace throughout Europe. Until the last weeks of his life Alexander remained faithful to the ideals of international cooperation which he had so strongly expressed in 1815 and the following years. In spite of pressure from Capodistrias for an active Russian policy in the Near East and even for a war with the Turks, the tsar continued to hope for concerted action by the powers to give Russia satisfaction for her grievances and the Greeks some security within the framework of the Ottoman Empire. The opposition of Britain, the ambiguities of Metternich's attitude, and the unreality of Alexander's own ideals doomed his efforts to failure. Dr. Schütz tells the story well and with sympathy, but says little that is new. The terminal date in the title is misleading, since the book ends with the death of Alexander in 1825.

M. S. ANDERSon

London School of Economics 